\title{
Editorial
}

\section{The Permissibility of Rotavirus Vaccines - A Personal Perspective}

\author{
Nordin $M M$
}

Pneumonia and diarrhoeal disease are the two top killers of children. UNICEF reports that these two diseases kill more than 2 million children each year. They make up $30 \%$ of childhood deaths under the age of 5 worldwide.

In the management of diarrhea, key interventions include; encouraging infant breastfeeding, improving access to clean drinking water, oral rehydration solutions and vaccination.

Funding Pneumococcal Conjugate Vaccines (PCV) and Rotavirus (RV) vaccines could prevent another one million children from dying every year.

In the hierarchy of the priorities of Islamic Jurisprudence (Maqasid as-Shariah); the preservation of life comes only second after the preservation of Deen. Life is a gift from Allah (SWT) and its protection and continuation is of utmost importance and urgency.

The sanctity of human life is emphasized in the Quran as, "... and if anyone saved a life, it would be as if he saved the life of all mankind." (Surah AlMa'idah, Verse 32).

The prophet (may peace be upon Him) related, "We are a people who do not eat until we are hungry. And if we eat, we do not eat to our fill." This narration among others is the backdrop to a powerful medical maxim "Prevention is better than cure".

This medical aphorism is further reinforced by the jurisprudence principle; "sadduz zaraik" - closing the doors of destruction.

These back to basics rulings alone are sufficient justification for the permissibility of immunisations to save the lives of innocent children, notwithstanding the issues related to the "halalness" of the vaccines. The presence of porcine elements in the manufacturing process of the two available RV vaccines namely Rotateq (MSD) and Rotarix (GSK) has triggered some measure of alarm in the Muslim medical fraternity, the Fatwa Councils and by extension the lay public. This however is not a new issue because it has been addressed by Muslim physicians, scientists, public health experts and jurists (fuqaha) who are at the cutting edge of vaccinology and child survival strategies.

The Oral Polio Vaccine (OPV) which has led to the virtual global eradication of polio utilizes small, virtually negligible amounts of trypsin derived from porcine origin, to disconnect the contiguous cells in the tissue culture. A similar technology is utilized in the manufacturing process of the RV vaccines.

The European Council of Fatwa \& Research in 2003 writes "Out of piety, some brother Muslim in various parts of the world, particularly in East Asia, have made the fatwa that it is not permissible to administer this vaccine to children, due to the fact that porcine trypsin is used in preparing it."

\section{They argued as follows:}

a) what God forbids is the partaking of pork, and trypsin has nothing to do with pork

b) even if we admit that trypsin is forbidden, the amount used in preparing the vaccine is negligible, if one applies the rule that "when the amount of water exceed 2 qillas, impurities no longer affect it"

c) supposing that trypsin is unclean, it is thoroughly filtered, that it leaves no traces whatsoever in the final vaccine

d) in case the three arguments forwarded are still insufficient, the haram (forbidden) are made permissible in cases of necessity.

In their concluding remarks they emphasized, "The Council urges Muslim leaders and officials at Islamic Centres not to be too strict in such matters that are open to considered opinion and that bring

Corresponds to: Dato ' Dr Musa Mohd Nordin, Cyberjaya University College of Medical Sciences (CUCMS) 
considerable benefits to Muslim children, as long as these matters involve no conflict with any definite text."
Such is the latitude of rationale and magnanimity of our scholars (fuqaha) unlike some, in addressing the bigger picture of child survival strategies and the advocacy of life saving vaccines.

\section{Manufacturing Process}

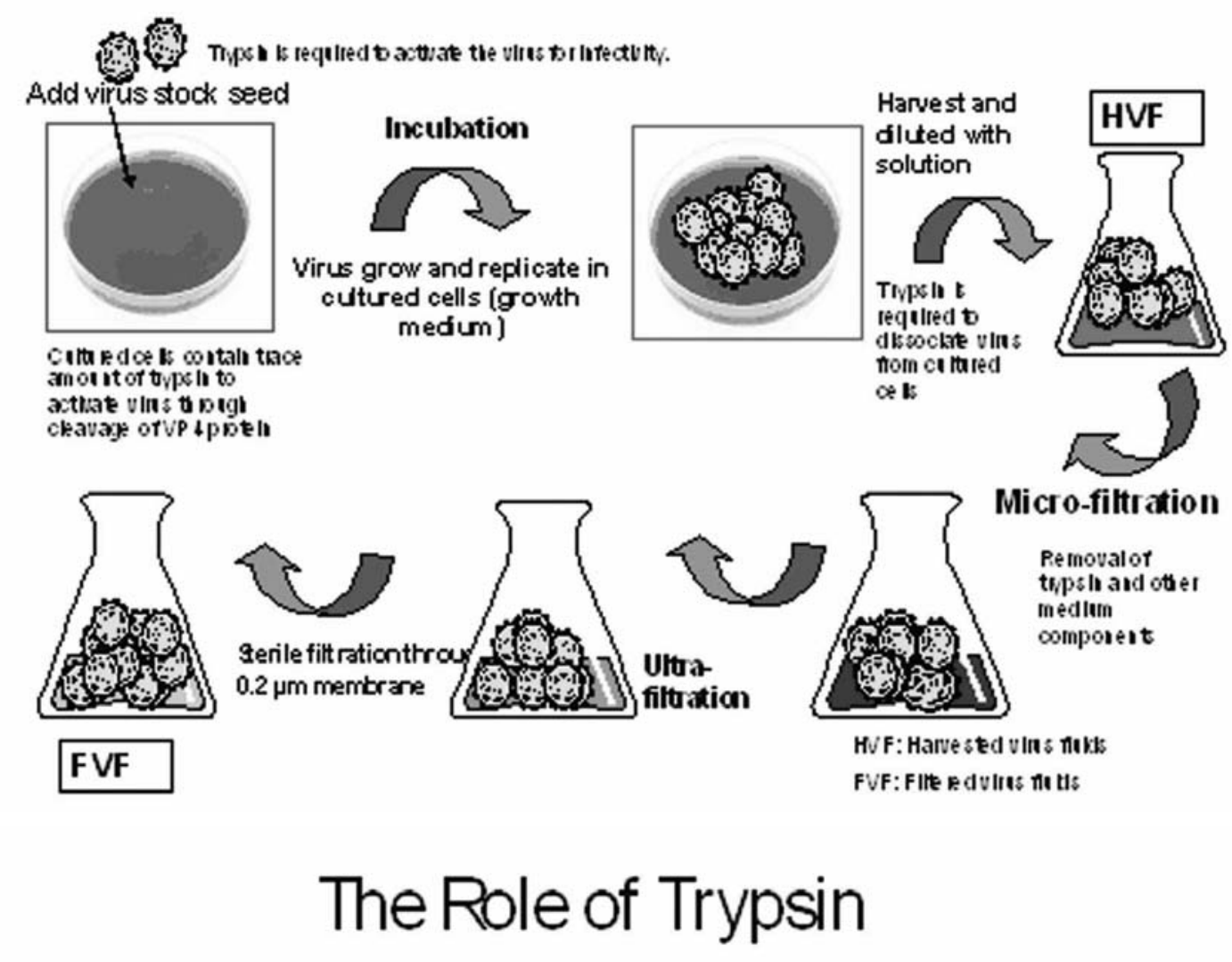

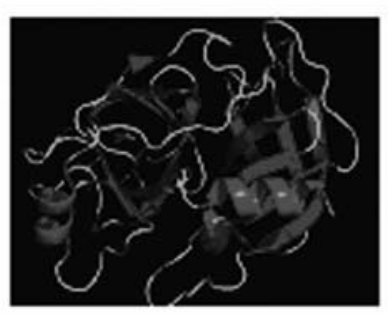

Crystal structure of Trypsin
- Trypsin is an enzyme, that cleaves protein into smaller fractions

- In vaccine manufacturing, trypsin is used to activate the virus and to separate the virus from cultured cells

- Enzymes function at extremely low concentration

- Trypsin is gamma irradiated before adding into cultured cells to ensure sterility

- Trypsin was eventually removed through various steps of filtration

- Trypsin of porcine origin was preferred based on safety reason (free of Transmissible Spongiform Encephalopathies) 